\title{
Viljan Fusarium-tartunta ja -toksiinit 2005-2006
}

Sari Rämö ${ }^{1)}$, Veli Hietaniemi ${ }^{1)}$ ja Päivi Parikka ${ }^{2)}$

1)MTT laboratoriot,31600 Jokioinen, sari.ramo@mtt.fi,veli.hietaniemi@mtt.fi

2)MTT Kasvintuotannon tutkimus, Peltokasvitutkimus, 31600 Jokioinen, paivi.parikka@mtt.fi

\section{Tiivistelmä}

Tavoitteena oli selvittää vuosina 2005-2006 suomalaista viljaa tartuttava Fusarium-lajisto sekä sen muodostamat mykotoksiinit. Edellinen kattavampi Fusarium-tutkimus suomalaisesta viljasta on peräisin 1970-luvun lopulta ja viljelyssä on tapahtunut sen jälkeen voimakkaita muutoksia, myös olosuhteet vaikuttavat muuttuneen jonkin verran. Kuivattuja, lajittelemattomia viljanäytteitä hankittiin joka puolelta maata 2005224 ja 2006 164, joista kaikista tehtiin Fusarium-määritykset maljakasvatuksin. Trikotekeeni- ja tsearalenonimäärityksiä ei tehty kaikista näytteistä.

Tutkimusvuodet olivat hyvin erilaisia sääoloiltaan ja olosuhteet suosivat eri Fusarium-lajeja. Fusarium- tartunta oli 2005 vuoden näytteissä homeiden kasvulle suotuisien olojen takia runsas. Deoksinivalenolin (DON) muodostajat Fusarium culmorum ja $F$. graminearum olivat yleisempiä ohralla ja kauralla, kevätvehnällä tartuntaa oli vähemmän. Syysviljanäytteitä tutkittiin vähän ja niissä myös Fusarium-tartunta oli alhaisin. T2/HT-2 muodostajia $F$. sporotrichioides ja $F$. langsethiae tavattiin runsaimmin kauranäytteistä, mutta myös jonkin verran ohralta. Alueellisesti lajit näyttivät olevan runsaimpia Itä-Suomesta kerätyissä näytteissä.Vuoden 2006 kuivan kesän sadossa DONmuodostajia oli niukemmin, sensijaan T2/HT-2 muodostajia ja $F$. poae-lajia oli runsaammin kuin 2005. Viimemainittuja, erityisesti $F$. langsethiae-lajia esiintyi varsin runsaana eräillä kauralajikkeilla. Lajia voidaan tavata kaikilta viljoilta ja kaikilta viljanviljelyalueilta, mutta tartunta on yleisin ja runsain kauralla. $F$. langsethiae on todettu pääasialliseksi trikotekeenitoksiinien tuottajaksi Norjassa ja laji näyttää myös olevan tärkein T2/HT-2 toksiinien tuottaja suomalaisessa viljassa, ohralla esiintyy myös samoja toksiineja tuottavaa F. sporotrichioides-lajia. Deoksinivalenolin tuottajista $F$. culmorum on yleisempi ja runsaampi kuin $F$. graminearum. Nivalenolia (NIV) muodostava $F$. poae viihtyy lämpimässä ja kuivassa, lajia esiintyy eniten kauralla.

EU on asettanut raja-arvoja DON:lle ja tsearalenonille prosessoimattomassa viljassa. Suurin sallittu DON-pitoisuus prosessoimattomassa kaurassa on $1750 \mu \mathrm{g} / \mathrm{kg}$ ja muissa viljoissa $1250 \mu \mathrm{g} / \mathrm{kg}$. Suurin sallittu tsearalenonipitoisuus prosessoimattomassa viljassa on $100 \mu \mathrm{g} / \mathrm{kg}$. Vuoden 2006 näytteistä ei mitattu raja-arvon ylittäviä pitoisuuksia. Vuonna 2005 sekä ohrasta että syysvehnästä mitattiin muutamia yli $1250 \mu \mathrm{g} / \mathrm{kg}$ ja kauralla yli $1750 \mu \mathrm{g} / \mathrm{kg}$ olevia DON-pitoisuuksia. Lisäksi yhden rehuohranäytteen tsearalenonipitoisuus oli yli $100 \mu \mathrm{g} / \mathrm{kg}$. NIV-pitoisuudet jäivät pääsääntöisesti alle $200 \mu \mathrm{g} / \mathrm{kg}$ tai sitä ei havaittu lainkaan. Molempina vuosina sekä ohrasta että kaurasta mitattiin yli 200 $\mu \mathrm{g} / \mathrm{kg}$ ja kauralla muutamia yli $500 \mu \mathrm{g} / \mathrm{kg}$ olevia T-2/HT-2-pitoisuuksia. Positiivista oli se, että näitä toksiineja ei havaittu lainkaan tai niiden yhteenlaskettu pitoisuus jäi alle $200 \mu \mathrm{g} / \mathrm{kg} \mathrm{n} .75 \%$ analysoiduista näytteistä.

Asiasanat: Fusarium, mykotoksiinit, trikotekeeni, tsearalenoni, vilja 


\section{Johdanto}

MTT on vuodesta 1999 tehnyt yhdessä Eviran ja ProAgrian kanssa viljojen jatkuvaa laadunseurantaa, jossa MTT:n työnä on ollut viljojen hometoksiiniseuranta. MTT laboratoriot on vuosittain tehnyt trikotekeeni-, tsearalenoni- ja okratoksiini A-analyysit kotimaisesta viljasta viljalajeittain.Tulokset on kytketty myös viljelyn taustatietoihin (www.agronet.fi/cerveg). Taustatiedoilla tarkoitetaan tässä maalajia, happamuutta, muokkausta, lannoitusta, kasvinsuojelutuoimia, esikasvitietoja, kylvö-ja puintipäiviä, korjuukosteutta, satoarviota jne. Tutkimus synnytti tarpeen selvittää myös suomalaisen viljan Fusarium-lajiston. "Selvitys Fusarium-lajeista ja niiden tuottamista mykotoksiineista suomalaisessa viljassa"-hanke (FinMyco-hanke) toteutettiin yhteistyönä MTT:n, Eviran ja Turun yliopiston biologian laitoksen kanssa vuosina 2005-2007. Edellinen kattavampi Fusarium-tutkimus suomalaisesta viljasta on peräisin 1970-luvun lopulta ja viljelyssä on tapahtunut sen jälkeen voimakkaita muutoksia, myös olosuhteet vaikuttavat muuttuneen jonkin verran.

\section{Aineisto ja menetelmät Näytteet}

Näytehankinta toteutettiin ostopalveluna ProAgrian kautta. Tästä oli saatu hyviä kokemuksia viljojen jatkuvassa laadunseurannassa. Näytteet oli tarkoitus kerätä ProAgrian lohkotietopankkitiloilta, jolloin viljelyn taustatiedot olisi helposti saatavilla. ProAgrian vuosittainen näytteenottosuunnitelma oli 150 näytettä eri puolilta Suomea siten, että kaikki viljalajit olisi edustettuina. Tavoitetta ei saavutettu: Näytemäärä jäi molempina vuosina alle 100 näytteen. Vuonna 2005 Uudeltamaalta ja Varsinais-Suomesta ei saatu ostopalvelunäytteitä lainkaan. Lisäksi 2005 näytteiden mukana toimitettiin vain suppeat viljelyn taustatiedot, joissa oli kerrottu lähinnä kylvö- ja puintipäivä, sekä korjuukosteus ja satoarvio. Vuonna 2006 ostopalvelunäytteissä ei ollut lainkaan edustettuna Etelä- ja Pohjois-Karjala sekä Etelä-Pohjanmaa. Tähän saattoi olla useita syitä: Vuoden 2006 korjuuaika oli aikainen ja näytehankinta käynnistettiin mahdollisesti liian myöhään. ProAgrian näytteenottajien keräysintoa saattoi heikentää myöhäinen tiedottaminen 2005 näytteiden tuloksista. MTT:n tutkimusasemat ja Satakunnan viljelijärengas toimittivat myös näytteitä ja niillä saatiin paikattua ostopalvelun jättämiä aukkoja. Kuivattuja, lajittelemattomia viljanäytteitä saatiin tutkimuksiin 2005 224 ja 2006 164. Satakunnasta kerättiin lisäksi kauran lajittelujätteitä, jotka olivat joko kuivurissa poistuvaa kevyttä roskaa ja/tai pieniä jyviä.

\section{MTT: $n$ analyysit}

Kaikista varsinaisista viljanäytteistä tehtiin Fusarium-määritykset maljakasvatuksin MTT kasvintuotannon tutkimuksella. 100 jyvää/näyte inkuboitiin PCNB-alustalla. Kasvustot eristettiin perunadekstroosialustalle (PDA). Fusarium-lajit tunnistettiin PDA-alustalta silmävaraisesti ja mikroskoopilla.

MTT Laboratoriot analysoi näytteistä hometoksiiniseurannan tavoin trikotekeenit ja tsearalenonin. Varastotoksiini, okratoksiini A jätettiin tutkimuksen ulkopuolelle, koska se ei ole Fusarium-lajien tuottama. Trikotekeenit analysoitiin 2005160 ja 2006 kaikista viljanäytteestä. MTT:n trikotekeenimenetelmällä voidaan analysoida 8 toksiinia: deoksinivalenoli (DON), diasetoksiskirpenoli (DAS), 3-ja 15-asetyylideoksinivalenolit (3 ja 15-AcDON), fusarenon X (F-X), nivalenolin (NIV), T-2- ja HT-2-toksiinit (Hietaniemi ym. 2004). Toksiinit uutetaan jauhetusta näytteestä asetonitriilin ja veden seoksella. Uute puhdistetaan Romer \#227 MycoSep SPE-kolonnilla. Yhdisteet tunnistetaan trimetyylisilyylijohdannaisinaan (TMSI) sisäisen standardin (ISTD) menetelmällä kaasukromatografi-massaspektrometrisesti (GC-MS) käyttäen kohdeioniseurantaa (SIM). Menetelmä on akkreditoitu. Koska tsearalenonin esiintyminen on ollut vähäistä MTT:n vuosittaisessa hometoksiiniseurannassa, se analysoitiin 2005 vain 30 ja 200658 viljanäytteestä. Tsearalenoni uutetaan rukiista, ohrasta ja vehnästä kuten trikotekeenit, mutta uutteen puhdistuksessa käytetään Romer \#226 MycoSep SPE-kolonnia (Romer Labs Methods). Kauran tsearalenonimäärityksessä uuttoliuoksena on asetonitriili.vesi:etikkahapposeos ja uute puhdistetaan

Bakerbond (SiOH) -SPE-kolonnilla (J.TBaker) (MTT:n sisäinen menetelmä: 2.18). Kuiviinhaihdutettu näyte liuotetaan veden ja asetonitriilin seokseen ja mitataan nestekromatografisesti (HPLC) fluoresenssidetektorilla. Tarvittaessa tulos voidaan varmistaa LC-MS-tekniikalla. 


\section{Tulokset ja tulosten tarkastelu \\ Fusarium-tulokset}

Tutkimusvuodet olivat hyvin erilaisia sääoloiltaan ja olosuhteet suosivat eri Fusarium-lajeja. Fusarium- tartunta oli 2005 kerätyissä näytteissä homeiden kasvulle suotuisien olojen takia runsas. Fusarium avenaceum (F.av) oli yleisin sekä ohralla, kevätvehnällä että kauralla. Deoksinivalenolin (DON) muodostajat Fusarium culmorum ja $F$. graminearum olivat yleisempiä ohralla ja kauralla (kuvat 1.ja 2.), kevätvehnällä tartuntaa oli vähemmän. Syysviljanäytteitä tutkittiin vähän ja niissä myös Fusarium-tartunta oli alhaisin. T2/HT-2 muodostajia $F$. sporotrichioides ja $F$. langsethiae tavattiin runsaimmin kauranäytteistä (kuva 3.), mutta myös jonkin verran ohralta (Thrane ym., 2004). Alueellisesti lajit näyttivät olevan runsaimpia Itä-Suomesta kerätyissä näytteissä.

Vuoden 2006 kuivan kesän sadossa DON-muodostajia oli niukemmin, sensijaan T2/HT-2 muodostajia ja $F$. poae-lajia oli runsaammin kuin 2005. Viimemainittuja, erityisesti $F$. langsethiaelajia esiintyi varsin runsaana eräillä kauralajikkeilla (kuva 3.). Juuri $F$. langsethiae on meillä varsin uusi laji, jonka esiintymisestä eri viljalajeilla ja eri osissa maatamme ei ole aikaisempaa tietoa. Lajia voidaan tavata kaikilta viljoilta ja kaikilta viljanviljelyalueilta, mutta tartunta on yleisin ja runsain kauralla. F. langsethiae on todettu pääasialliseksi trikotekeenien tuottajaksi Norjassa (Kosiak ym., 2003). ja laji näyttää myös olevan tärkein T2/HT-2 toksiinien tuottaja suomalaisessa viljassa, vaikka erityisesti ohralla esiintyy myös samoja toksiineja tuottavaa F. sporotrichioides-lajia. Deoksinivalenolin tuottajista $F$. culmorum on yleisempi ja runsaampi kuin $F$. graminearum. Nivalenolia (NIV) muodostava $F$. poae viihtyy lämpimässä ja kuivassa, lajia esiintyy eniten kauralla

Kuva 1. Fusarium culmorum ja F.graminearum eri ohralajikkeissa 2005 ja 2006
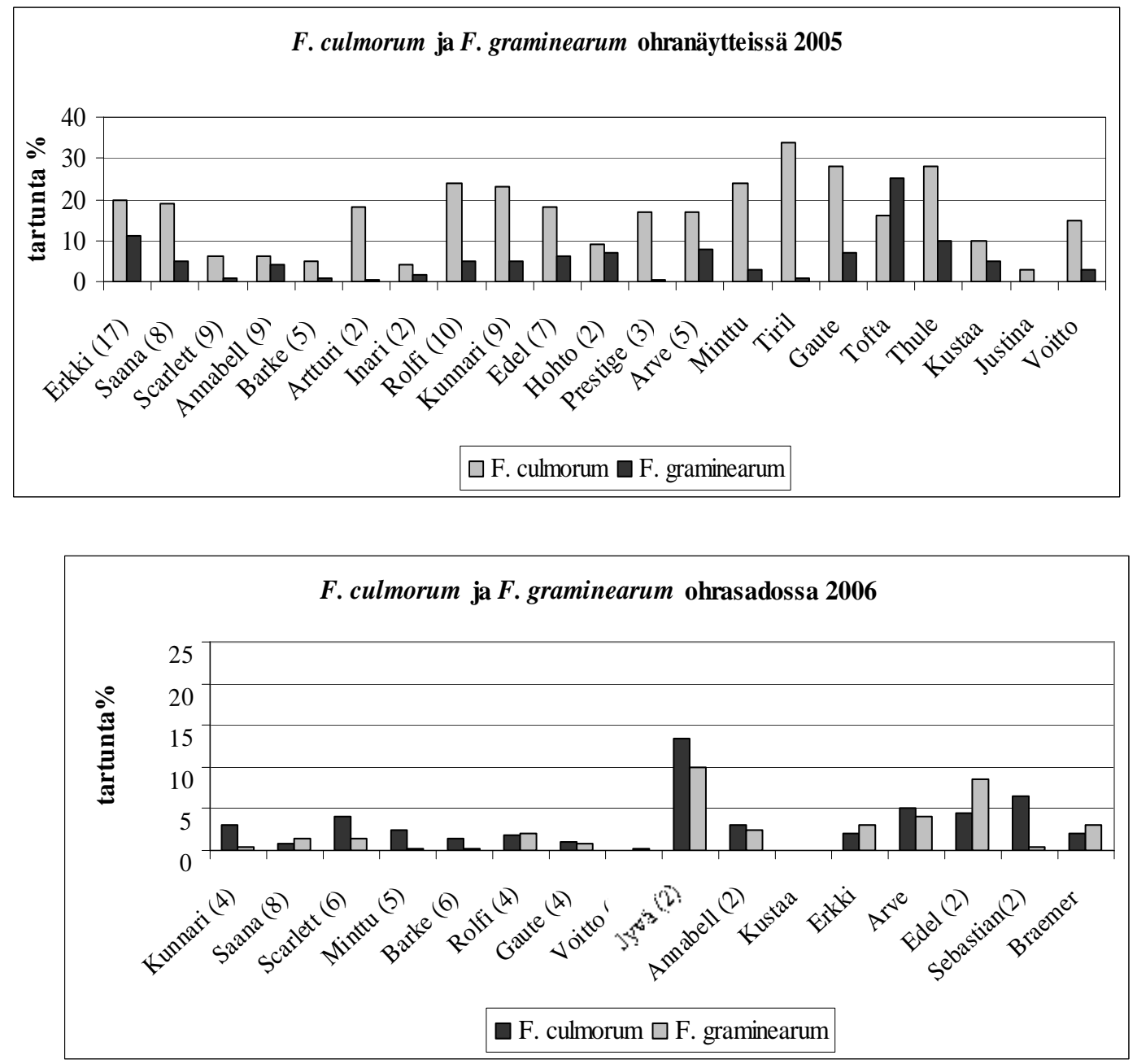
Kuva 2. Fusarium culmorum ja F.graminearum eri kauralajikkeissa 2005 ja 2006
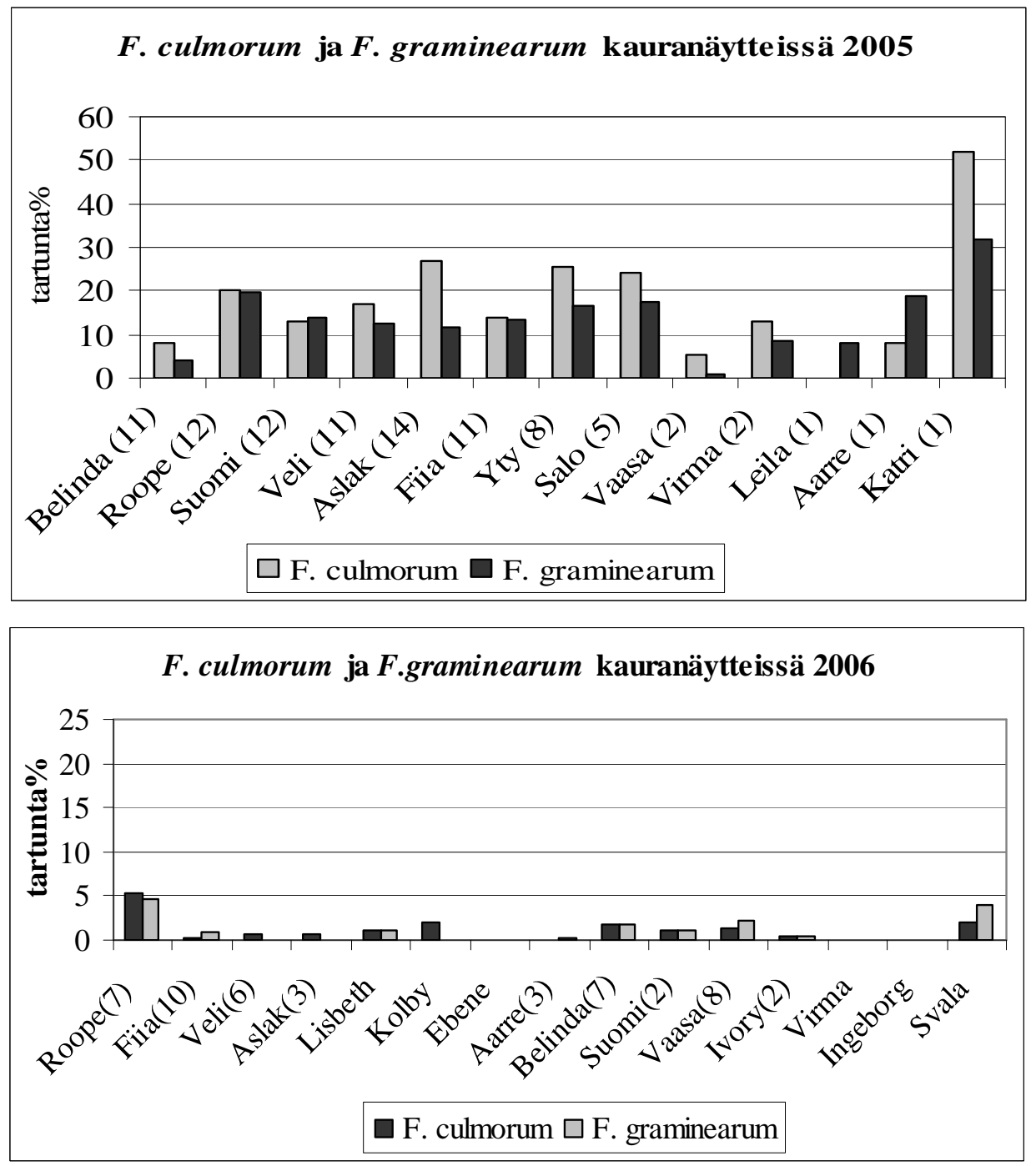
Kuva 3. Fusarium sporotrichioides ja F.langsethiae eri kauralajikkeissa 2005 ja 2006
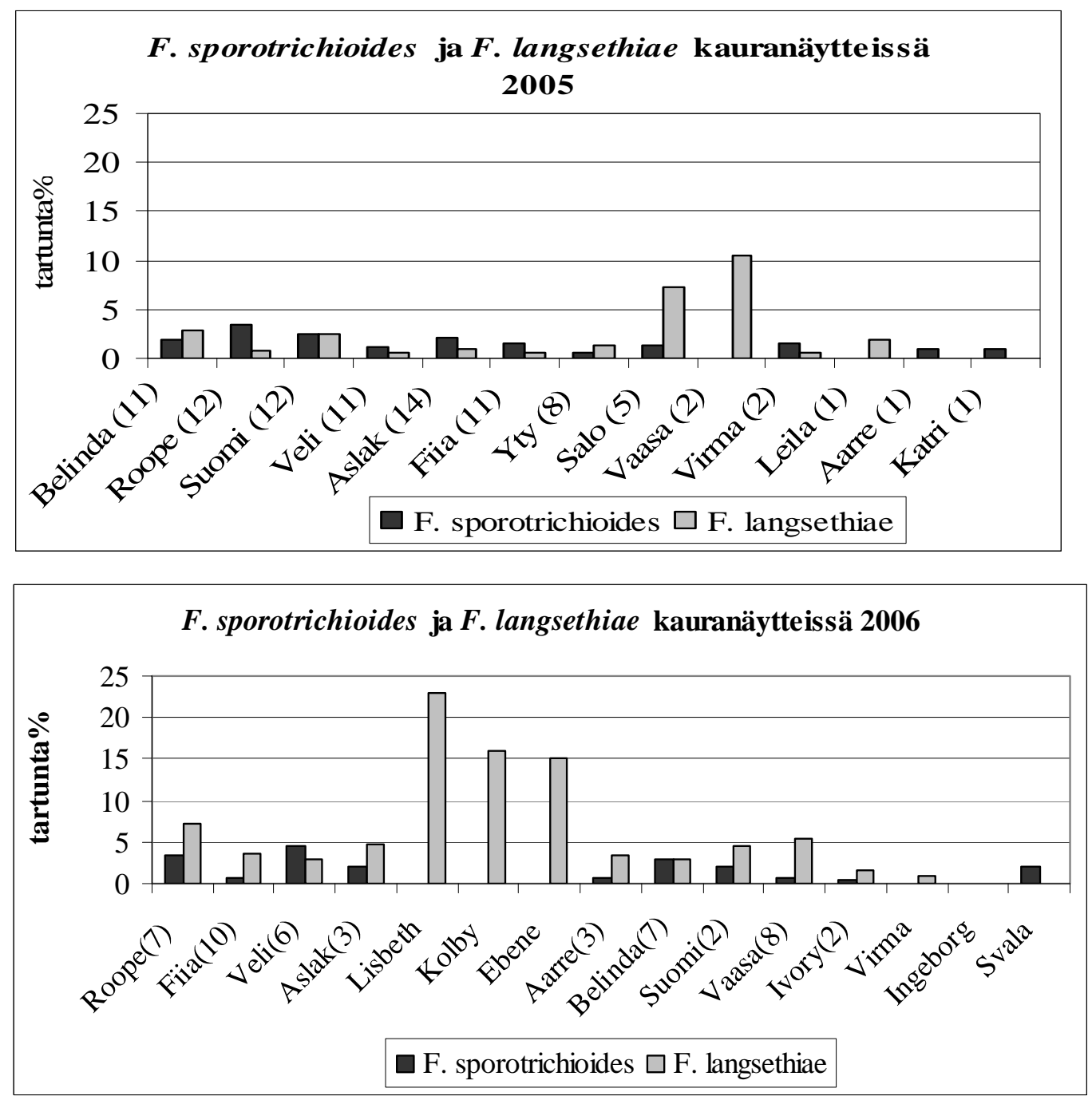

\section{Fusarium-toksiinitulokset}

EU on asettanut raja-arvoja DON:lle ja tsearalenonille prosessoimattomassa viljassa (Komission asetus (EY) N:o 1881/2006). Suurin sallittu DON-pitoisuus prosessoimattomassa kaurassa ja durum vehnässä on $1750 \mu \mathrm{g} / \mathrm{kg}$ ja muissa viljoissa $1250 \mu \mathrm{g} / \mathrm{kg}$. Suurin sallittu tsearalenonipitoisuus prosessoimattomassa viljassa on $100 \mu \mathrm{g} / \mathrm{kg}$.

Näytteistä ei havaittu lainkaan seuraavia toksiineja: DAS, F-X ja 15-AcDON. 3-AcDON:a esiintyi vuonna 2005. Se liittyy selkeästi kohonneisiin DON-pitoisuuksiin. Vuonna 2005 sekä ohrasta että kevätvehnästä mitattiin muutamia yli $1250 \mu \mathrm{g} / \mathrm{kg}$ ja kauralla yli $1750 \mu \mathrm{g} / \mathrm{kg}$ olevia DONpitoisuuksia (taulukko 1). Korkein DON-pitoisuus oli kaurasta mitattu $9300 \mu \mathrm{g} / \mathrm{kg} .2006$ ei mitattu raja-arvon ylittäviä DON-pitoisuuksia. Syysvehnässä ja rukiissa DON:n esiintyminen oli vain vähäistä sekä 2005 että 2006. T-2/HT-2 toksiineille ei ole toistaiseksi voimassa EU raja-arvoja, vaikka ne ovat DON:a toksisempia. Huolestuttavaa oli se että molempina vuosina sekä ohrasta että kaurasta mitattiin yli $200 \mu \mathrm{g} / \mathrm{kg}$ ja kauralla muutamia yli $500 \mu \mathrm{g} / \mathrm{kg}$ olevia pitoisuuksia (taulukko 2). Vuonna 2005 korkein T-2/HT-2 pitoisuus oli kaurasta mitattu $1900 \mu \mathrm{g} / \mathrm{kg}$ ja vuonna 2006 myös kaurasta mitattu $1700 \mu \mathrm{g} / \mathrm{kg}$. Positiivista oli se, että näitä toksiineja ei havaittu lainkaan tai niiden yhteenlaskettu pitoisuus jäi alle $200 \mu \mathrm{g} / \mathrm{kg} \mathrm{n}$. $75 \%$ analysoiduista näytteistä. Syysviljoista näitä ei havaittu lainkaan. 
Taulukko 1. Vuoden 2005 ja 2006 näytteistä määritetyt DON-pitoisuudet ja niiden jakautuminen viljalajeittain ja pitoisuusluokittain

\begin{tabular}{|c|c|c|c|c|c|c|c|c|c|c|}
\hline \multirow{3}{*}{$\begin{array}{l}\text { Vilja- } \\
\text { laji }\end{array}$} & \multicolumn{8}{|c|}{ Deoksinivalenoli (DON): kpl näytteitä (vaihteluväli: $\mu \mathrm{g} / \mathrm{kg}$ ) } & & \\
\hline & \multicolumn{2}{|c|}{$<200 \mu \mathrm{g} / \mathrm{kg}$} & \multicolumn{2}{|c|}{$200-1250 \mu \mathrm{g} / \mathrm{kg}$} & \multicolumn{2}{|c|}{$1250-1750 \mu \mathrm{g} / \mathrm{kg}$} & \multicolumn{2}{|c|}{$>1750 \mu \mathrm{g} / \mathrm{kg}$} & \multicolumn{2}{|c|}{ Yhteensä } \\
\hline & 2005 & 2006 & 2005 & 2006 & 2005 & 2006 & 2005 & 2006 & 2005 & 2006 \\
\hline Ruis & $\begin{array}{c}6 \\
\text { (n.d.-41) }\end{array}$ & $\begin{array}{c}8 \\
\text { (n.d. }-<25)\end{array}$ & 0 & 0 & 0 & 0 & 0 & 0 & $\begin{array}{c}6 \\
\text { (n.d.-41) }\end{array}$ & $\begin{array}{c}8 \\
\text { (n.d. }-<25\end{array}$ \\
\hline Ohra & $\begin{array}{c}21 \\
\text { (n.d.-170) }\end{array}$ & $\begin{array}{c}58 \\
\text { (n.d.- 90) }\end{array}$ & $\begin{array}{c}25 \\
(210-1100)\end{array}$ & $\begin{array}{c}3 \\
(210-990) \\
\end{array}$ & $\begin{array}{c}4 \\
(1250-1590)\end{array}$ & 0 & $\begin{array}{c}1 \\
(4750)\end{array}$ & 0 & $\begin{array}{c}51 \\
\text { (n.d.-4750) }\end{array}$ & $\begin{array}{c}61 \\
\text { (n.d.-990) }\end{array}$ \\
\hline $\begin{array}{l}\text { Kevät- } \\
\text { vehnä }\end{array}$ & $\begin{array}{c}11 \\
\text { (n.d.-140) }\end{array}$ & $\begin{array}{c}32 \\
\text { (n.d.-49) }\end{array}$ & $\begin{array}{c}6 \\
(220-1230)\end{array}$ & 0 & $\begin{array}{c}3 \\
(1450-1710)\end{array}$ & 0 & $\begin{array}{c}2 \\
(2000-2220)\end{array}$ & 0 & $\begin{array}{c}22 \\
\text { (n.d.-2220) }\end{array}$ & $\begin{array}{c}32 \\
\text { (n.d.-49) }\end{array}$ \\
\hline \begin{tabular}{|l|} 
Syys- \\
vehnä \\
\end{tabular} & $\begin{array}{c}5 \\
\text { (n.d.-150) } \\
\end{array}$ & $\begin{array}{c}4 \\
\text { (n.d) }\end{array}$ & 0 & 0 & 0 & 0 & 0 & 0 & $\begin{array}{c}5 \\
(n . d-150) \\
\end{array}$ & $\begin{array}{c}4 \\
\text { (n.d) }\end{array}$ \\
\hline Kaura & $\begin{array}{c}10 \\
\text { (n.d.-150) }\end{array}$ & $\begin{array}{c}36 \\
\text { (n.d.-19) }\end{array}$ & $\begin{array}{c}48 \\
(200-1230)\end{array}$ & $\begin{array}{c}22 \\
(200-820)\end{array}$ & $\begin{array}{c}3 \\
(1450-1650)\end{array}$ & 0 & $\begin{array}{c}12 \\
(1760-9300)\end{array}$ & 0 & $\begin{array}{c}72 \\
\text { (n.d.-9300) }\end{array}$ & $\begin{array}{c}58 \\
\text { (n.d.-820) }\end{array}$ \\
\hline Muut & 0 & 0 & $\begin{array}{c}1^{*} \\
(1040)\end{array}$ & $\begin{array}{c}1 \\
(220)\end{array}$ & 0 & 0 & $\begin{array}{c}2 \\
(2570-3840)\end{array}$ & 0 & $\begin{array}{c}3 \\
(1040-3840)\end{array}$ & $\begin{array}{c}1 \\
(220)\end{array}$ \\
\hline yht. & $\begin{array}{c}53 \\
\text { (n.d.-170) }\end{array}$ & $\begin{array}{c}138 \\
\text { (n.d.- } 90)\end{array}$ & $\begin{array}{c}80 \\
(200-1230)\end{array}$ & $\begin{array}{c}26 \\
(200-990)\end{array}$ & $\begin{array}{c}10 \\
(1250-1710)\end{array}$ & 0 & $\begin{array}{c}17 \\
(1760-9300)\end{array}$ & 0 & $\begin{array}{c}160 \\
\text { (n.d.-9300) }\end{array}$ & $\begin{array}{c}164 \\
\text { (n.d.-990) }\end{array}$ \\
\hline
\end{tabular}

n.d. = yhdistettä ei havaittu

* $\quad=$ murskattu säilötty kaura

Muut $=$ kauranäyte, jossa mukana muita siemeniä

Taulukko 2. Vuoden 2005 ja 2006 näytteistä määritetyt T-2/HT-2 -pitoisuudet ja niiden jakautuminen viljalajeittain ja pitoisuusluokittain

\begin{tabular}{|c|c|c|c|c|c|c|c|c|c|c|}
\hline \multirow{3}{*}{\begin{tabular}{|l} 
Vilja-laji \\
Vuosi
\end{tabular}} & \multicolumn{8}{|c|}{ T-2 + HT-2 -toksiinit: kpl näytteitä (vaihteluväli: $\mu \mathrm{g} / \mathrm{kg}$ ) } & & \\
\hline & \multicolumn{2}{|c|}{ n.d. } & \multicolumn{2}{|c|}{$<200 \mu \mathrm{g} / \mathrm{kg}$} & \multicolumn{2}{|c|}{$200-500 \mu \mathrm{g} / \mathrm{kg}$} & \multicolumn{2}{|c|}{$>500 \mu \mathrm{g} / \mathrm{kg}$} & \multicolumn{2}{|c|}{ Yhteensä } \\
\hline & 2005 & 2006 & 2005 & 2006 & 2005 & 2006 & 2005 & 2006 & 2005 & 2006 \\
\hline Ruis & 6 & 8 & 0 & 0 & 0 & 0 & 0 & 0 & $\begin{array}{c}6 \\
\text { (n.d) }\end{array}$ & $\begin{array}{c}8 \\
\text { (n.d) }\end{array}$ \\
\hline Ohra & 31 & 38 & $\begin{array}{c}18 \\
(<25-120)\end{array}$ & $\begin{array}{c}20 \\
(<25-130)\end{array}$ & $\begin{array}{c}2 \\
(250-280)\end{array}$ & $\begin{array}{c}2 \\
(210)\end{array}$ & 0 & $\begin{array}{c}1 \\
(760)\end{array}$ & $\begin{array}{c}51 \\
\text { (n.d.-280) }\end{array}$ & $\begin{array}{c}61 \\
\text { (n.d.-760) }\end{array}$ \\
\hline $\begin{array}{l}\text { Kevät- } \\
\text { vehnä }\end{array}$ & 22 & 31 & 0 & $\begin{array}{c}1 \\
(26)\end{array}$ & 0 & 0 & 0 & 0 & $\begin{array}{c}22 \\
\text { (n.d) }\end{array}$ & $\begin{array}{c}32 \\
\text { (n.d.-26) }\end{array}$ \\
\hline \begin{tabular}{|l|} 
Syys- \\
vehnä \\
\end{tabular} & 5 & 4 & 0 & 0 & 0 & 0 & 0 & 0 & $\begin{array}{c}5 \\
\text { (n.d.) } \\
\end{array}$ & $\begin{array}{c}4 \\
\text { (n.d.) } \\
\end{array}$ \\
\hline Kaura & 28 & 23 & $\begin{array}{c}25 \\
(<25-150)\end{array}$ & $\begin{array}{c}24 \\
(<25-200)\end{array}$ & $\begin{array}{c}12 \\
(250-480)\end{array}$ & $\begin{array}{c}6 \\
(210-470)\end{array}$ & $\begin{array}{c}8 \\
(540-1940)\end{array}$ & $\begin{array}{c}5 \\
(510-1700)\end{array}$ & $\begin{array}{c}73 \\
\text { (n.d.-1940) }\end{array}$ & $\begin{array}{c}58 \\
\text { (n.d.-1700) }\end{array}$ \\
\hline Muut & 3 & 0 & 0 & $\begin{array}{c}1 \\
(31)\end{array}$ & 0 & 0 & 0 & 0 & $\begin{array}{c}3 \\
\text { (n.d.) }\end{array}$ & $\begin{array}{c}1 \\
(31)\end{array}$ \\
\hline yhteensä & 95 & 104 & $\begin{array}{c}43 \\
(<25-150)\end{array}$ & \begin{tabular}{|c}
46 \\
$(<25-200)$
\end{tabular} & $\begin{array}{c}14 \\
(250-480)\end{array}$ & $\begin{array}{c}8 \\
(210-470)\end{array}$ & $\begin{array}{c}8 \\
(540-1940)\end{array}$ & $\begin{array}{c}6 \\
(510-1700)\end{array}$ & $\begin{array}{c}160 \\
\text { (n.d.-1940) }\end{array}$ & $\begin{array}{c}164 \\
\text { (n.d.-1700) }\end{array}$ \\
\hline
\end{tabular}

NIV-pitoisuudet jäivät molempina vuosina pääsääntöisesti alle $200 \mu \mathrm{g} / \mathrm{kg}$ tai sitä ei havaittu lainkaan. Korkein oli NIV-pitoisuus oli kaurasta mitattu $1320 \mu \mathrm{g} / \mathrm{kg}$, myös ohrassa oli yksittäisiä korkeita pitoisuuksia vuonna 2005. Vuonna 2005 tsearalenonia havaittiin kuudesta näytteestä, joista yhden rehuohranäytteen tsearalenonipitoisuus oli $230 \mu \mathrm{g} / \mathrm{kg}$. Vuonna 2006 vain yhdestä näytteestä havaittiin tsearalenonia. 
Varsinaisten viljanäytteiden lisäksi trikotekeenit määritettiin muutamista kauran lajittelujätenäytteistä. Vuonna 2005 näistä mitattiin huomattavan korkeita toksiini-pitoisuuksia. Vuonna 2006 pitoisuudet olivat vuoden 2005 tuloksia alhaisemmat. Niissä jätefraktiossa, jotka muodostuivat kuivurissa poistuvasta kevyestä roskasta, DON, NIV, T-2 ja HT-2 -pitoisuudet saattoivat olla kymmenkertaiset niihin jäte-fraktiohin verrattuna, jotka muodostuivat pääasiassa pienistä jyvistä.

\section{Johtopäätökset}

Fusarium-tartunta oli 2005 sadossa selvästi runsaampi kuin 2006 johtuen erilaisista sääoloista. Kesän 2005 kosteus suosi erityisesti F. avenaceum-, F. culmorum ja F. framinearum-lajeja. Toisaalta kuivana kesänä 2006 korostui F. langsethiae-lajin määrä muiden sienten tartunnan ollessa vähäisempää. F. langsethiae-lajia tavattiin eniten kauralta, mutta myös ohralta. Kevätvehnällä lajia oli vähiten, samoin se oli harvinainen syysviljoilla. Lajia löytyi paitsi etelän viljelyalueilta, myös pohjoisesta. Kaikkiaan kauralla ja ohralla Fusarium-tartunta oli runsainta. lajikkeiden välillä oli eroja tartunnassa. Lajien runsaudessa taas saattoi havaita jonkinlaista eroa eri viljelyalueiden välillä, mikä oli seurausta erilaisista sääoloista ja osin eri lajikkeista.

FinMyco-näytteistä tehdyt trikotekeenimääritykset kasvattivat MTT:n vuosittaisen hometoksiinitulosaineiston yli kaksinkertaiseksi. Vuonna 2006 FinMycon DON-tulokset olivat samaa tasoa kuin hometoksiiniseurannassa: Kevätvehnällä DON-tulokset jäivät alle $200 \mu \mathrm{g} / \mathrm{kg}$. FinMycon kauran ja ohran DON-pitoisuudet jäivät alle raja-arvojen, tosin hometoksiiniseurannan ohrissa esiintyi yksi raja-arvon ylittävä pitoisuus (1700 $\mu \mathrm{g} / \mathrm{kg})$. Vuonna 2005, jolloin Fusarium-lajejakin esiintyi runsaammin, näytemäärän kasvattaminen 120 näytteestä 280 näytteeseen toi esiin useampia DONraja-arvon ylityksiä kuin mitä vuosittaisessa hometoksiiniseurannassa oli esiintynyt. Olisi tärkeä saada selville 2005 vuodelta laajemmat viljelyn taustatiedot, jotta saataisiin lisätietoa siihen, miksi epävakaisenakin vuosina, joillakin alueilla/lohkoilla voidaan kasvattaa lähes hometoksiineista vapaata viljaa.

Lajittelulla voidaan selvästi vähentää viljaerän hometoksiinipitoisuuksia ja siten parantaa sen laatua elintarvike-, siemen- tai rehuviljaksi. Lajittelujätteen käyttäminen eläinten rehuksi ei ole kovin suositeltavaa tämän tutkimushankkeen tulosten perusteella.

\section{Kirjallisuus}

Hietaniemi V, Kontturi M, Rämö S, Eurola M, Kangas A, Niskanen M and Saastamoinen M (2004) Contents of trichothecenes in oats during official variety, organic cultivation and nitrogen fertilization trials in Finland. Agricultural and Food Science 13: 54-67

Romer Labs Methods: Zearalenone HPLC MycoSep ${ }^{\mathrm{TM}} 226$ Method

MTT:n sisäinen menetelmä 2.18, Okratoksiini A:n ja tsearalenonin määrittäminen kaurasta nestekromatografisesti

Thrane U; Adler A; Clasen P-E; Galvano F; Langseth W; Lew H; Logrieco A; Nielsen K F; Ritieni A (2004) Diversity in metabolite production by Fusarium langsethiae, Fusarium poae and Fusarium sporotrichioides. International Journal of Food Microbiology 95:257-266

Kosiak B; Torp M ; Skjerve E; Thrane U (2003) The prevalence and distribution of Fusarium species in Norwegian cereals: a survey. Acta Agriculturae Scandinavica, Section B, Soil and Plant Science 53:168-176.

Komission asetus (EY) N:o 1881/2006, annettu 19 päivänä joulukuuta 2006, tiettyjen elintarvikkeissa olevien vierasaineiden enimmäismäärien vahvistamisesta 